Proceedings of the 2018 International Scientific Conference 'Economic Sciences for Agribusiness and Rural Economy' No 1, Warsaw, 7-8 June 2018, pp. 75-80

\title{
SOCIAL SUSTAINABILITY IN AGRICULTURAL FARMS WITH DIFFERING ECONOMIC SIZE IN THE EU COUNTRIES
}

\author{
Bazyli Czyżewski, PhD, Associate Professor; Dawid Dobrowolski, BA²; \\ Anna Matuszczak, PhD, Associate Professor ${ }^{3}$; Paweł Śmidoda, BA ${ }^{4}$; \\ Tomasz Szwon, BA ${ }^{5}$
}

1,3 Faculty of Economics, Poznań University of Economics and Business

2, 4, 5 Student Scholarly Association of Food Economics, Poznań University of Economics and Business

\begin{abstract}
The aim of the paper was to identify different levels of social sustainability in farms of various economic sizes (6 sizes) in the EU countries. The study is based on the Sustainable Value (SV) method, which is valueoriented, measured as the sustainability of agriculture at the micro-economic level (e.g. agricultural farm). To be able to compare farms among themselves, an RTC was calculated. The FADN database for the years 2004-2015 was used in the article, analysing very small (I) and very large (VI) farms more closely. It identifies countries, where farms made a positive contribution to social sustainability and those, compared to the EU average, which need mainly institutional support in order to bridge the gap with the best.
\end{abstract}

Keywords: social sustainability, agricultural farms, economic size, the EU countries

JEL codes: Q01, Q56, J43, O13

\section{INTRODUCTION}

Sustainable development is most often analysed in its economic, social and environmental aspects (Kates, Parris and Leiserowitz, 2005; Zegar, 2012). The social sustainability on which the authors have focused is primarily seen in terms of employment and income. Employment is regarded both in quantitative terms when the employment rate increases, and in qualitative terms when the skills of the workforce are upgraded. Many authors stress the importance of in- creasing employment in rural areas (supported, among others, by Community funds), which is strongly correlated with the decreasing rate of social exclusion, and thus increasing social governance, by reducing depopulation of these areas and improving the quality of life (Basiago, 1999; Weingaertner and Moberg, 2009; Chatzinikolaou, Manos and Bournaris, 2012; Subić, Jeločnik and Jovanović, 2013). For example, Torres et al. (2016) indicated that running ecological farms improves the situation of the local community

${ }^{1}$ Corresponding author: al. Niepodległości 10, Poznań, Poland, bazyli.czyzewski@ue.poznan.pl, +4861 8543017

${ }^{2}$ Corresponding author: al. Niepodległości 10,61-875 Poznań, Poland, dawiddobrowolski@onet.pl, +48 618543017

${ }^{3}$ Corresponding author: al. Niepodległości 10,61-875 Poznań, Poland, anna.matuszczak@ue.poznan.pl, +4861 8543017

${ }^{4}$ Corresponding author: al. Niepodległości 10,61-875 Poznań, Poland, pawel.smidoda1@wp.pl,+4861 8543017

${ }^{5}$ Corresponding author: al. Niepodległości 10,61-875 Poznan, Poland, tomasz.szwon@gmail.com, +4861 8543017 
and is particularly desirable in areas characterised by relatively high unemployment, thus increasing their social order. Also the quality of employment, i.e. qualifications and education, as well as human and social capital in a broad sense are strongly linked to social sustainability, as they have a direct impact on the income of the agricultural population (Wolz, Fritzsch and Reinsberg, 2006; Czerna-Grygiel, 2010; Flora and Roesch-McNally, 2014; Knapik, 2014; Latruffe et al., 2016). The income aspect is also raised in a different context - as a result of sustainable farming. Examples from various countries (Argentina, Austria, Bulgaria and other developing countries, including the Third World) show that sustainable agriculture is better than industrial agriculture because it does not have a negative impact on the rural population, impoverishing farmers and thus depriving them of opportunities for development (McKenzie, 2004; Berlan, 2013; Kwasek, Prandecki and Zegar, 2015; Severi, 2016; Bachev, 2017; Gizicki-Neundlinger and Güldner, 2017). Hediger (2008) and Bacon et al. (2012) note that, i.a. sustainable agriculture reduces some of the social costs of industrial farming, in particular the exposure of workers and rural communities to pesticides, while at the same time leading to an overall improvement in the quality of life in rural areas, maintaining cultural traditions and biodiversity, including through appropriate investment (Bock, 2012). Simultaneously, in a wider context, it is an element of territorial development, which in turn leads to sustainable social development (Hediger, 2008; Wilson, 2009).

\section{MATERIALS AND METHODS}

The aim of the paper is to indicate the differentiation of the level of social balance in farms of various economic sizes (6 sizes) in the EU countries. We will use Sustainable Value (SV) method, which is a valueoriented method, developed as a means of measuring agricultural sustainability at microeconomic level (e.g. agricultural farm). This enables a synthetic assessment of a farm's contribution to farming sustainability, taking into account the efficiency resulting from using economic, social and environmental resources in comparison to the opportunity cost (Figge and Hahn, 2005; Van Passel et al., 2007; Illge, Hahn nad Figge, 2008). In the authors opinion ESV has many advantages comparing to the standard DEA approach, since it also measures the monetary value of 'contribution to the sustainability' that should be borne to achieve it or was paid in surplus. Thus, it gives much more information useful for policymakers than a linear ordering. As noted above, the authors pointed to one of the pillars of sustainability - social sustainability. The calculation formula for determining the SV of farms in the regions needs to indicate a benchmark farm, which was the average value of variables adopted for the analysis for the analysed EU countries. The calculation formula for determining the SSV of the farms is as follows:

$$
S S V_{i}=\frac{1}{m} \sum_{j=1}^{m} r_{i j}\left(\frac{y_{i j}}{r_{i j}}-\frac{y b_{i j}}{r b_{i j}}\right)
$$

where:

$S S V_{i}$ - the social sustainable value afferent to a farm from country $i$;

$r_{i j}, r b_{i j}$ - the resource quantity of type $j$ and country $i$ of the analysed farm, i.e. of the farm considered as reference system;

$y_{i j}, y b_{i j}$ - the return of resources of the analysed and benchmark farm; $i=1, \ldots, n$ is the country and $j=1, \ldots, m$ is the type of analysed resource.

Through its contents, SSV indicates the absolute size of the value created in a sustainable manner by the agricultural farms of various countries of the EU in each economic sizes. To take into account the size effects and to make comparisons between farms of various countries, we can calculate the indicator return to cost ratio $(R T C i)$. This one shows the relative contribution of farms from various countries to the sustainable performance compared to the benchmark:

$$
R T C_{i}=\frac{y_{i}}{y_{i}-S S V_{i}}
$$

where:

$y_{i}$ - represents the created value (farm net income);

$S S V_{i}$ - social sustainable value of the average agricultural farm of country $i$. 

No 1, Warsaw, 7-8 June 2018, pp. 75-80

The FADN database for the years 2004-2015 was used, analysing very small farms (I), medium small farms (III) and very large farms (VI) in greater detail. We use the following variables as an input indicator: unpaid labour input (SE015), paid labour input (SE020), wages paid (SE370) and as an output: farm net income (SE420).

\section{RESULTS}

The conducted analyses indicate that the calculated RTC value for individual economic size of average EU farms allows for their delimitation to those where the rate is relatively high, above 1 for all classes, such as Austria, Belgium, Ireland, Spain or Italy (Table 1). These countries can therefore be considered as making a positive contribution to social sustainability from their farms. This means that the ratio of the allocated outlays and effects is higher than the average in the EU-27. The relatively worst situation is observed in Bulgarian, Cypriot, Danish, Latvian, Polish, Slovak, Swedish and Hungarian farms, where the RTC indicator for the selected research period in all economic size classes are relatively low, below 1 . Therefore, it can be concluded that agriculture in these countries requires institutional support that would allow for the improvement of qualifications, education and investment, which could have a positive impact on the efficiency of the labour factor.

Table 1. Average RTC value for agricultural farms of the EU-27 in 2004-2015

\begin{tabular}{|c|c|c|c|c|c|c|c|c|c|}
\hline Class & Austria & Belgium & Bulgaria & Cyprus & $\begin{array}{c}\text { Czech } \\
\text { Republic }\end{array}$ & Denmark & Estonia & Finland & France \\
\hline I & - & - & 0.34 & 0.49 & - & - & 2.57 & - & - \\
\hline II & 2.51 & - & 0.21 & 0.45 & 1.57 & 0.22 & 0.86 & 1.16 & 1.02 \\
\hline III & 2.21 & 1.64 & 0.18 & 0.34 & 1.14 & 0.38 & 0.80 & 1.68 & 1.04 \\
\hline IV & 2.12 & 1.62 & 0.16 & 0.29 & 0.97 & 0.59 & 0.82 & 1.24 & 1.01 \\
\hline V & 1.66 & 1.77 & 0.19 & 0.57 & 0.41 & 0.41 & 0.50 & 0.88 & 0.89 \\
\hline VI & - & 1.41 & 0.82 & 0.66 & 0.30 & 0 & 0.49 & 0.62 & 0.96 \\
\hline$x$ & Greece & Germany & Hungary & Ireland & Italy & Lithuania & Luxembourg & Latvia & Malta \\
\hline I & 1.94 & - & 0.65 & 4.79 & 1.19 & 1.64 & - & 1.00 & 1.74 \\
\hline II & 1.41 & - & 0.66 & 2.56 & 1.11 & 1.52 & - & 0.74 & 1.62 \\
\hline III & 1.09 & 0.86 & 0.63 & 2.46 & 1.10 & 1.77 & 0.55 & 0.50 & 1.09 \\
\hline IV & 0.90 & 1.16 & 0.65 & 2.35 & 1.09 & 1.26 & 1.12 & 0.44 & 0.93 \\
\hline $\mathrm{V}$ & 0.82 & 1.15 & 0.60 & 2.05 & 1.34 & 1.01 & 1.63 & 0.35 & 0.87 \\
\hline VI & - & 0.64 & 0.53 & - & 3.27 & 0.96 & 1.07 & 0.58 & - \\
\hline$x$ & Poland & Portugal & Romania & Slovakia & Slovenia & Spain & Sweden & Netherlands & $\begin{array}{c}\text { United } \\
\text { Kingdom }\end{array}$ \\
\hline I & 0.99 & 0.99 & 0.94 & - & 0.15 & 1.52 & - & - & - \\
\hline II & 0.78 & 0.74 & 0.76 & 0.60 & 0.75 & 1.21 & 0.60 & - & 1.78 \\
\hline III & 0.93 & 0.66 & 0.66 & 0.16 & 0.99 & 1.10 & 0.52 & 0.56 & 0.89 \\
\hline IV & 0.98 & 0.75 & 0.64 & 0.15 & 1.06 & 1.11 & 0.89 & 0.35 & 0.98 \\
\hline $\mathrm{V}$ & 0.79 & 0.78 & 0.74 & 0.01 & 0.97 & 1.12 & 0.67 & 1.02 & 0.93 \\
\hline VI & 0.78 & 1.22 & 2.78 & 0 & - & 1.51 & 0.23 & 0.69 & 1.22 \\
\hline
\end{tabular}

Source: own study based on FADN data. 
It should be noted that the calculations of SSV and then RTC indicator were carried out horizontally, i.e. within each economic size separately, so for example the social sustainability of very small farms was considered between EU countries in the years 2004-2015, where farms of this size were located. Against this background, the best results were reported by Irish households (4.79), and the lowest by Slovenian households $(0.15)$ and Bulgarian households (0.34) (cf. Table 1). This was due to the fact that in Ireland the average annual employment of the labour force in these farms is about twice lower $(0.75$ AWU) than in Slovenia or Bulgaria, additionally the average annual income from Irish agricultural family farm (EUR 3,527) is thirteen times higher than in Slovenia (very small Slovenian farms had negative incomes in 2008, 2014 and 2015) and about twice as high as in Bulgaria. The group contributing to social sustainability also includes Estonian, Greek, Spanish, Italian, Lithuanian and Maltese farms.

For comparison, very large farms can be identified with the highest RTC indicator in Italy (3.27 and positive SSV) and the lowest RTC indicator in Slovakia (0). Such drastic differences are due, firstly, to the fact that the average annual income from a Slovak agricultural farms was negative (EUR - 18,600) in the analysed period, while in Italy it was EUR 360,200. Secondly, the approach to employment of labour was radically different - in Italy 6.2 AWU, in Slovakia 56.1 AWU. Thirdly, the relation between own and hired work was also different - in Italy it was in relation of 2 to 4 AWU, in Slovakia it was of 0.2 to 56 AWU. As a result, the wage costs were completely different, while in Slovakia they were two and a half times lower per one employee. All these observations explain the highest position of Italian farms in the group of very large farms and the lowest of Slovak farms, which, like others with a low RTC indicator (where SSV is negative), require the attention of both national and Community institutions.

Dynamic analyses were also made in the researched period, which generally show, first of all, that the position of farms of a given economic size in the 'old' EU countries is relatively stable and with a few exceptions it is most often above 1 , second, the position of some countries of the 'new' EU (e.g. Poland, Hungary) was growing in the analysed period (Fig. 1), which may prove that they are making up for 'losses' to the best. This observation can only be partially confirmed in the case of the largest farms, i.e. while half of the countries of the 'old' EU achieve RTC above 1 in the analysed period (i.e. SSV is positive, they contribute to social sustainability), there are no such countries among the 'new' farms (except in the outgoing Romanian case). In addition, we can say that the level of RTC indicator remains relatively stable (Fig. 2), which perpetuates the distance in social sustainability of this class of farms in the EU countries.

As was mentioned above, the analyses did not refer to vertical comparisons - between economic size classes. So we are not deciding in this article which farms - small, medium-sized or large - are more socially sustainable. It can be assumed that this is mainly due to the fact, that individual farms with different economic size were organised differently. For comparison, the smallest farms are based primarily on their own, family labour resources, not taking advantage of almost completely employed work and not paying salaries to employees. It can be concluded that these are primarily family farms, which are part

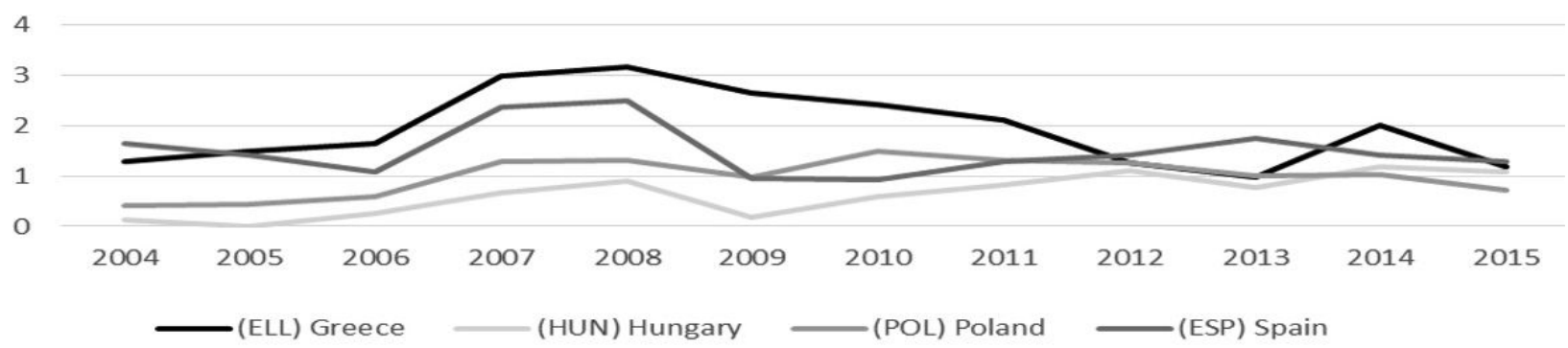

Figure 1. Average value of SSV for very small farms (class I) in selected EU-27 countries in the years 2004-2015 Source: own study based on FADN data. 


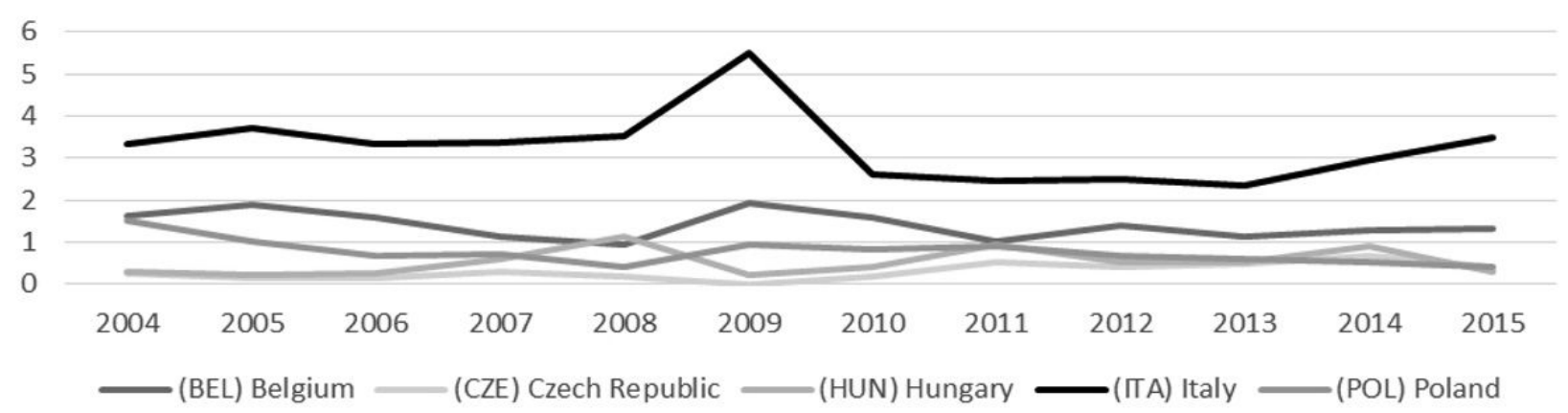

Figure 2. Average value of SSV for very large farms (class VI) in selected EU-27 countries in the years 2004-2015 Source: own study based on FADN data.

of the European agricultural model (Davidova and Thomson, 2014; Burja and Burja, 2016).

Depending on the country, they occupy a more or less significant place in the agrarian structure, however, they constitute a vast majority of the total EU population and although their income is relatively low, which may have a negative impact on social sustainability, they perform many social functions (creation of jobs for owners and family members, protection against poverty, ensuring food security) and environmental (protection of agricultural land with high natural value, preservation of biodiversity and attractiveness of the area, shaping the rural landscape). On the other hand, the largest farms, most often organised in the form of enterprises or cooperatives, are mainly based on hired work, generating usually satisfactory incomes (Bachev, 2017), often being the only employer in rural areas.

\section{CONCLUSIONS}

The conducted analyses allow to identify countries, where farms make a positive contribution to social sustainability by considering the relation between the inputs (unpaid labour input, paid labour input, wages paid) and the results obtained (farm net income) in agricultural activity. Generalising it can be concluded that positive SSV, and thus RTC indicator above 1, in all classes of economic size of farms occurs only in a few countries of the 'old' EU. Against this background, farms from the 'new' EU countries look worst. Dynamic analyses of the analysed period show that the position of farms of a given economic size in the 'old' EU countries is relatively stable, while the position of some countries of the 'new' EU (e.g. Poland, Hungary) was growing in the analysed period, which is a positive phenomenon.

\section{Acknowledgements}

This article is founded by the National Science Centre in Poland (grant 2016/21/B/HS4/00653).

\section{REFERENCES}

1. Bachev, H. (2017). Socio-economic and environmental sustainability of Bulgarian farms. Agricultural and Resource Economics: International Scientific E-Journal, 3 (2), pp. 5-21.

2. Bacon, C., Getz, C., Kraus, S., Holland, K. (2012). The social dimensions of sustainability in diversified, industrial and hybrid farming systems. Retrieved from: food. berkeley.edu/wp-content/uploads/.../Social-Dimensions.pdf [Accessed 02.05.2018].

3. Basiago, A. (1999). Economic, social, and environmental sustainability in development theory and urban planning practice. Environmentalist, 19, pp. 145-161.

4. Berlan, A. (2013). Social Sustainability in Agriculture: An Anthropological Perspective on Child Labour in Cocoa Production in Ghana. The Journal of Development Studies, 49 (8), pp. 1088-1100.

5. Bock, B. (2012). Social innovation and sustainability; how to disentangle the buzzword and its application in the field of agriculture and rural development. Studies in Agricultural Economics, 114, pp. 57-63.

6. Burja, C., Burja, V. (2016). The economic farm size and sustainable value. Disparities between Romania and the EU states. Annals of the Constantin Brâncuşi University of Târgu Jiu. Economy 1. 
7. Chatzinikolaou, P., Manos, B., Bournaris, T. (2012). Classification of rural areas in Europe using social sustainability indicators. In: Proceedings of Conference 'Towards a Sustainable Bio-economy: Economic Issues and Policy Challenges'. Retrieved from: http://ageconsearch.umn.edu/record/124104/files/Chatzinikolaou_ Manos_Bournaris_Classification $\% 20 \mathrm{of} \% 20$ rural $\% 20 \mathrm{a}$ reas\%20in\%20Europe $\% 20$ using\%20social\%20sustain ability\%20indicators.pdf [Accessed 02.05.2018].

8. Czerna-Grygiel, J. (2010). Uwarunkowania zrównoważonego rozwoju społeczności lokalnej [Determinants of sustainable development of the local community]. Zrównoważony rozwój obszarów wiejskich wybrane aspekty społeczne [Sustainable development of rural areas Selected social aspects]. Economicus, Szczecin, pp. 73-92.

9. Davidova, S., Thomson, K. (2014). Family farming in Europe; Challenges and prospects. EC Brussel. Retrieved from: http://www.europarl.europa.eu/RegData/etudes/note/join/2014/529047/IPOL-AGRI_NT \%282014\%29529047_EN.pdf [Accessed 04.05.2018].

10. Figge, F., Hahn, T. (2005). The Cost of Sustainability Capital and the Creation of Sustainable Value by Companies. Journal of Industrial Ecology, 9, pp. 47-58.

11. Flora, C., Roesch-McNally, G.E. (2014). Sustainable Agriculture and Social Justice: A Conversation with Dr. Cornelia Flora. Journal of Critical Thought and Praxis, 3 (1), \# 3.

12. Gizicki-Neundlinger, M., Güldner, D. (2017). Surplus, Scarcity and Soil Fertility in Pre-Industrial Austrian Agriculture - The Sustainability Costs of Inequality, Sustainability. Retrieved from: http://www.mdpi. com/2071-1050/9/3/332/htm [Accessed 01.05.2018].

13. Hediger, W. (2008). Agriculture's Multifunctionality, Sustainability, and Social Responsibility. Agecon search. Retrieved from: ageconsearch.umn.edu/bitstream/36854/2/Hediger.pdf [Accessed 10.05.2018].

14. Illge, L., Hahn, T., Figge, F. (2008). Applying and Extending the Sustainable Value Method to Agriculture - an Overview. In: Proceedings of 12th Congress of the European Association of Agricultural Economists - EAAE, Ghent.

15. Kates, R.W., Parris, T.M., Leiserowitz, A.A. (2005). What Is Sustainable Development? Goals, Indicators, Values, and Practice. Environment: Science and Policy, 47 (3), pp. 8-21.

16. Knapik, W. (2014). Wybrane aspekty rozwoju polskich obszarów wiejskich na tle koncepcji zrównoważonego rozwoju oraz zakorzenionych rynków [Selected aspects of the development of Polish rural areas against the background of the concept of sustainable development and rooted markets]. Roczniki Naukowe SERiA, 61 (5), pp. 109-113.

17. Kwasek, M., Prandecki, K., Zegar, J.S. (2015). From the research on socially-sustainable agriculture. Institute of Agricultural and Food Economics, Warszawa.

18. Latruffe, L., Diazabakana, A., Bockstaller, C., Desjeux, Y., Finn, J., Kelly, E., Ryan, M., Uthes, S. (2016). Measurement of sustainability in agriculture: a review of indicators. Studies in Agricultural Economics, 118 (3), pp. 123-130.

19. McKenzie, S. (2004). Social sustainability towards some definition. Hawke Research Institute Working Paper Series 27.

20. Severi, C. (2016). Social sustainability and resilience of the rural communities: the case of soy producers in Argentina the expansion of the production from Latin America to Africa. Agricultural sciences. Université d'Avignon, Avignon.

21. Subić, J., Jeločnik, M., Jovanović, M. (2013). Evaluation of social sustainability of agriculture within the Carpathians in the Republic of Serbia. Scientific Papers. Management, Economic Engineering in Agriculture and Rural Development, 13 (2), pp. 411-416.

22. Torres, J., Valera, D.L., Belmonte, L.J., Herrero-Sánchez, C. (2016). Economic and Social Sustainability through Organic Agriculture: Study of the Restructuring of the Citrus Sector in the 'Bajo Andarax' District (Spain), Sustainability. Retrieved from: www.mdpi. com/2071-1050/8/9/918/pdf [Accessed 10.05.2018].

23. Van Passel, S., Nevens, F., Mathijs, E., Van Huylenbroeck, G. (2007). Measuring farm sustainability and explaining differences in sustainable efficiency. Ecological Economics, 62 (1), pp. 149-161.

24. Weingaertner, C., Moberg, A. (2009). Exploring Social Sustainability: Learning from perspectives on Urban Development and Companies and Products. Retrieved from: https://www.diva-portal.org/smash/get/diva 2:378611/FULLTEXT02.pdf [Accessed 10.05.2018].

25. Wilson, A. (2009). Social and Ecological Implications of Sustainable Agriculture. In: The 9th International Students Summit on Food, Agriculture and Environment in the New Century, Tokyo. Retrieved from: http://www. nodai.ac.jp/cip/iss/english/9th_iss/fullpaper/1-2-5msuwilson.pdf [Accessed ...?...].

26. Wolz, A., Fritzsch, J., Reinsberg, K. (2006). The Impact of Social Capital on Farm and Household Income: Results of a Survey among Individual Farmers in Poland. Post-Communist Economies, 18 (1), pp. 85-99.

27. Zegar, J.S. (2012). Współczesne wyzwania rolnictwa [The modern challenges facing agriculture]. Wydawnictwo Naukowe PWN, Warszawa. 